\title{
Seasonal changes of water quality in a tropical shallow and eutrophic reservoir in the metropolitan region of Recife (Pernambuco-Brazil)
}

\author{
FÁBIO H.P.C. DE OLIVEIRA ${ }^{1}$, ANDRÉ L.S. CAPELA E ARA ${ }^{2}$, CESAR H.P. MOREIRA ${ }^{3}$, \\ OSMAN O. LIRA ${ }^{4}$, MARIA DO ROSÁRIO F. PADILHA ${ }^{2}$ and NEIDE K.S. SHINOHARA ${ }^{2}$ \\ ${ }^{1}$ Companhia Pernambucana de Saneamento, (COMPESA), Laboratório de Hidrobiologia, \\ Rua Dois Irmãos, 1012, Apipucos, 52071-440 Recife, PE, Brasil \\ ${ }^{2}$ Universidade Federal Rural de Pernambuco, (UFRPE), Departamento de Gastronomia, \\ Rua Dois Irmãos, s/n, Apipucos, 52171-900, Recife, PE, Brasil \\ ${ }^{3}$ Universidade Federal Rural de Pernambuco, (UFRPE), Departamento de Ciências Biológicas, \\ Rua Dois Irmãos, s/n, Apipucos, 52171-900 Recife, PE, Brasil \\ ${ }^{4}$ Fundação Nacional da Saúde (FUNASA), Laboratório de Controle da Qualidade da Água, \\ Av. Conselheiro Rosa e Silva, 1489, Aflitos, 52050-020 Recife, PE, Brasil
}

Manuscript received on March 18, 2014; accepted for publication on July 7, 2014

\begin{abstract}
This study investigated the water quality in an urban eutrophic reservoir in Northeastern Brazil, considering the influence of seasonality. Monthly, samples were collected in the sub-surface reservoir. The following abiotic variables were analyzed: temperature, $\mathrm{pH}$, dissolved oxygen, apparent color, turbidity, conductivity, fluoride, total nitrogen, chlorides, total dissolved solids, total hardness, iron, copper, manganese, aluminum, chlorophyll-a and phaeophytin. Total and thermotolerant coliforms were analyzed according to APHA (2012). Cyanobacteria density was quantified through its biomass. The data were analyzed using one- way ANOVA and Pearson correlation test. Higher values mean phytoplankton biomass $\left(26.3 \mathrm{~mm}^{3} \cdot \mathrm{L}^{-1}\right)$ occurred in the dry season, especially Planktothrix agardhii and Geiterinema amphibium, which occurred in 100\% of samples. High trophic state index was detected throughout the year. Seasonality exerted some influence on both biotic and abiotc variables, leading to changes in water quality of the reservoir.
\end{abstract}

Key words: coliforms, cyanobacteria, reservoir, trophic state.

\section{INTRODUCTION}

The increase in population density coupled with the increase in the release of domestic and industrial effluents in water bodies is the phenomenon called eutrophication, which enriches the environment with nutrients, primarily nitrogen and phosphorus, increasing the productivity of the environment and depreciating the quality of water (Fernandes et al. 2009, Esteves 2013).

Correspondence to: Fábio Henrique Portella Corrêa de Oliveira E-mail: fportella@gmail.com
Blooms of cyanobacteria are associated to eutrophic water conditions, although it is known that blooms of microalgae occur seasonally in some environments, as a response to conditions that change the stability of the water column (Affe and Barboni 2012). Some reservoirs are naturally eutrophic, but, in many others, the excess intake of nutrients is of anthropogenic origin (Calijuri et al. 2006). This event may cause social, economic and environmental impacts, since cyanobacteria 
are potentially producing secondary metabolites with toxic properties that can affect human health (Siqueira and Oliveira-Filho 2005).

In addition to cyanobacteria, presence of bacteria of the coliform group, primarily Escherichia coli, are a risk to the health of the consumer population, due to the possibility of airing of diseases such as diarrhea and dysentery (Ahmed et al. 2013).

Due to the interaction between biotic and abiotic factors, including seasonality, in an ecosystem, the presence of certain chemicals, even in small concentrations, can be reflected in risk to human health, with prejudice to the water quality in question (Esteves 2013).

The Apipucos dam, located in the metropolitan region of Recife (Pernambuco, Brazil) is undergoing a process of degradation of its water due to the release of untreated sewage and trash, even though it is considered an urban conservation unit, according to the municipal law No. 16.609 of December 18/2000 (Recife 2000).

In Brazil, the National Environmental Council (CONAMA) seeks to control the discharge of pollutants into the environment, by prohibiting the release of harmful or hazardous levels for humans and other life beings. The study of seasonal water quality of the Apipucos Dam is of great importance, since its waters are used for subsistence, fishing and recreation in the region, and could serve as a route of transmission of various kinds of diseases of major public health impact, carried by water and food consumed by the needy community in the surroundings.

In shallow reservoirs, despite the small volume of water per area, a complex set of factors regulates aquatic dynamics, which is represented, in tropical regions, especially by the rain and radiation (Fonseca and Bicudo 2008), probably influencing the diversity and density of cyanobacteria and, therefore, the quality of the water reservoir. However, the knowledge of this type of ecosystem, mainly urban and not intended for public supply is scarce, especially in northeastern Brazil.
Thus, the present work aimed to analyze the water quality of the reservoir of Apipucos, considered shallow, eutrophic, urban and not for public supply, with respect to biotic and abiotic variables, including some metals, as well as contribute to a survey on the species of the cyanobacteria found.

\section{MATERIALS AND METHODS}

AREA OF STUDY

The reservoir of Apipucos is located in the West zone of the city of Recife (Pernambuco, Brazil), at the coordinates $8^{\circ} 01^{\prime} 14^{\prime \prime} \mathrm{S}, 34^{\circ} 56^{\prime} 00^{\prime \prime} \mathrm{W}$ and is a sub-basin of the Capibaribe River, being built to control flooding of this river. It has an area of $2.9 \mathrm{~km}^{2}$, average volume of $556,375 \mathrm{~m}^{3}$ and average depth of $2.5 \mathrm{~m}$ (Neumann-Leitão et al. 1989). The occurrence of free-floating Macrophytes is expressive, represented mainly by Eichhornia crassipes (Mart.). Due to its historical, cultural and environmental values, its water is considered and environmental protection area, even though the dumping of effluents in its waters has depreciated its quality.

\section{SAMPLING AND LABORATORY TESTING}

Water samples were collected monthly between December 2011 and November 2012 at a same point located in the limnetic zone of the reservoir and during two climatic periods: rainy season (March to August/12) and dry period (December/11 to February/12 and September/12 to November/12). Samples were collected for qualitative and quantitative analysis of the community of cyanobacteria. All samples were obtained in duplicate in sub-surface reservoir (approximately 30 $\mathrm{cm}$ deep). All samples were collected, preserved and packaged in accordance with APHA (2012).

Air temperature $\left({ }^{\circ} \mathrm{C}\right)$ and precipitation $(\mathrm{mm})$ were obtained from the National Institute for Space Research (INPE) and from the Pernambuco Agency of Water and Climate (APAC), respectively, in meteorological stations located within a maximum $2 \mathrm{~km}$ of distance from the place of sampling. 
In situ measurements were made for the determination of $\mathrm{pH}$, using a potentiometer (Digimed, DMHP-2); temperature $\left({ }^{\circ} \mathrm{C}\right)$ using a Mercury thermometer and transparency of the water $(\mathrm{m})$ using a Secchi disk. The euphotic zone (Zeu) was calculated according to Cole (1994).

Measurements of dissolved oxygen (mg.L $\left.\mathrm{L}^{-1}\right)$, apparent color (UH), turbidity (UT), conductivity $\left(\mu \mathrm{S} . \mathrm{cm}^{-1}\right)$, fluoride $\left(\mathrm{mg} . \mathrm{L}^{-1}\right)$, total nitrogen $\left(\mathrm{mg} . \mathrm{L}^{-1}\right)$, chlorides (mg. $\left.\mathrm{L}^{-1}\right)$, total dissolved solids (STD, mg. $\left.\mathrm{L}^{-1}\right)$, total hardness $\left(\mathrm{mg} . \mathrm{L}^{-1}\right)$, iron (mg. $\left.\mathrm{L}^{-1}\right)$, copper (mg. $\left.\mathrm{L}^{-1}\right)$, manganese $\left(\mathrm{mg} . \mathrm{L}^{-1}\right)$, aluminum $\left(\mathrm{mg} . \mathrm{L}^{-1}\right)$, chlorophyll-a $\left(\mu \mathrm{g} . \mathrm{L}^{-1}\right)$, phaeophytin $\left(\mu \mathrm{g} . \mathrm{L}^{-1}\right)$, total coliforms and termotolerantes (cel.100 $\left.\mathrm{mL}^{-1}\right)$ were made in accordance with APHA (2012).

Cyanobacteria identification was done until the lowest possible taxonomic hierarchical level with the use of specialized literature (Komárek and Anagnostidis 1989, 1999, 2005, Komárek and Cronberg 2001). Density (cel. $\mathrm{mL}^{-1}$ ) was determined by the method of Sedgewick-Rafter (APHA 2012). Biomass $\left(\mathrm{mm}^{3} . \mathrm{L}^{-1}\right)$ was calculated from values of cell biovolume ( $\mathrm{n}=30$ ), based on Hillebrand et al. (1999).

Carlson's trophic state index was used for characterization of the ecosystem (Carlson 1977). Molar rate TN:TP was determined according to Downing and McCauley (1992). For the estimation of nutrient limitation, $\mathrm{TN}: \mathrm{TP}<20$ was considered as limited by nitrogen; TN:TP $>38$ was considered as limited by phosphorus (Kosten et al. 2009).

Analysis of variance (one-way ANOVA) was used to test the significance of differences in biotic and abiotic variables $(p<0.05)$ between dry and rainy seasons, using software Statistica 10 (test version). A Pearson correlation matrix was constructed for establishing the relationships of biotic with abiotic parameters $(\mathrm{p}<0.05)$.

\section{RESULTS}

Data of air temperature and precipitation confirmed the occurrence of two distinct seasons in the region where the Apipucos Dam is located. The dry and rainy seasons were characterized by average temperatures of $24.4^{\circ} \pm 0.7^{\circ} \mathrm{C}$ and $25.7 \pm 0.8^{\circ} \mathrm{C}$, respectively. Rainfall was higher in the rainy season (189 $\mathrm{mm}$ ) in comparison to the drought season (98 $\mathrm{mm}$ ). The temperature values (ANOVA: $\mathrm{F}=9.91$, $\mathrm{p}<0.05$ ) and rainfall (ANOVA: $\mathrm{F}=10.2, \mathrm{p}<0.05$ ) were significantly different between stations.

Limitation of nitrogen throughout the study period was observed. Even though the average concentrations have not shown significant differences between the rainy and dry periods, higher values were observed during the rainy period in relation to the drought period, with minimum and maximum values of $1.88 \mu \mathrm{mol}$ (dry) and $14.28 \mu \mathrm{mol}$ (rainy). Dissolved oxygen concentrations ranged between $5.00 \mathrm{mg} . \mathrm{L}^{-1}$ (dry) and $8.15 \mathrm{mg} . \mathrm{L}^{-1}$ (rainy), although, on average, there was no significant difference between periods. With respect to $\mathrm{pH}$, significant difference was observed between the periods (ANOVA: $\mathrm{F}=8.08$ $\mathrm{p}<0.05$ ), with circumneutral values throughout the study, although with slight tendency to alkalinization during the dry period, coinciding with the period of greatest biomass of cyanobacteria. No significant differences were observed between the periods for the other parameters, as noted in table I.

In the reservoir, values of chlorophyll-a, TP and transparency classified this water as hypereutrophic throughout the year.

Analyses of coliforms total and thermotolerant revealed densities exceeding $2.4 .10^{3} \mathrm{cel} .100 \mathrm{~mL}^{-1}$ during the present study, i.e. they are above the maximum value allowed, which is $1.0 .10^{3} \mathrm{cel} . \mathrm{mL}^{-1}$, based on determination of BRASIL (2005).

Throughout the study, five taxa of Cyanophyta Division belonging to the orders Oscillatoriales, Chroococcales and Nostocales, were identified, all of which in the rainy season, and four during the drought season, with absence of Cylindropespermopsis raciborskii Seenaya \& Suba Raju (Table II).

In this study, biomass of cyanobacteria over $4.0 \mathrm{~mm}^{3} \cdot \mathrm{L}^{-1}$ in all samples was observed. Greatest biomass of all species of cyanobacteria occurred 
TABLE I

Values of variables in the Apipucos reservoir, Pernambuco, Brazil, between December 2011 and November 2012; Min = minimum value; Max = maximum value; SD $=$ standard deviation

\begin{tabular}{|c|c|c|c|c|c|c|c|c|}
\hline \multirow[t]{2}{*}{ Variables } & \multicolumn{4}{|c|}{ Dry Period } & \multicolumn{4}{|c|}{ Rainy Period } \\
\hline & Min & Max & Average $(n=12)$ & DP & Min & Max & Average $(n=12)$ & SD \\
\hline $\mathrm{pH}$ & 7.0 & 7.6 & 7.4 & 0.3 & 6.7 & 6.9 & 6.8 & 0.1 \\
\hline Euphotic zone - Zeu (m) & 0.62 & 1.19 & 0.88 & 0.23 & 1.14 & 1.38 & 1.26 & 0.17 \\
\hline Temperature $\left({ }^{\circ} \mathrm{C}\right)$ & 27.5 & 29.0 & 28.3 & 0.7 & 27.0 & 30.0 & 28.6 & 1.3 \\
\hline Dissolved Oxygen - DO (mg.L $\left.\mathrm{L}^{-1}\right)$ & 6.1 & 8.2 & 7.1 & 1.1 & 5.0 & 8.0 & 6.3 & 1.6 \\
\hline Apparent color (UH) & 34 & 164 & 104 & 65 & 66 & 80 & 73 & 7 \\
\hline Turbidity (NTU) & 38.0 & 42.1 & 40.4 & 1.7 & 17.3 & 28.8 & 23.1 & 3.8 \\
\hline Conductivity $\left(\mu \mathrm{S} . \mathrm{cm}^{-1}\right)$ & 877 & 1,164 & 1,003 & 147 & 993 & 1,422 & 1,161 & 229 \\
\hline Fluoride (mg. $\left.\mathrm{L}^{-1}\right)$ & 0.0 & 0.5 & 0.15 & 0.27 & 0.0 & 0.0 & 0.0 & 0.0 \\
\hline Total nitrogen - NT ( $\mu \mathrm{mol})$ & 1.9 & 7.3 & 5.1 & 2.9 & 8.9 & 14.3 & 11.3 & 2.7 \\
\hline Total phosphorus-TP $(\mu \mathrm{mol})$ & 0.25 & 0.97 & 0.50 & 0.15 & 0.09 & 0.64 & 0.37 & 0.10 \\
\hline Chlorophyll-a $\left(\mu \mathrm{g} . \mathrm{L}^{-1}\right)$ & 198 & 230 & 210 & 13 & 150 & 210 & 185 & 22 \\
\hline Phaeophytin $\left(\mu \mathrm{g} . \mathrm{L}^{-1}\right)$ & 3.7 & 49.2 & 25.6 & 30.5 & 16.0 & 26.3 & 22.2 & 4.5 \\
\hline Chlorides (mg. $\left.\mathrm{L}^{-1}\right)$ & 263 & 1,749 & 854 & 788 & 53 & 440 & 281 & 202 \\
\hline Total Dissolved Solids - TDS (mg.L $\left.\mathrm{L}^{-1}\right)$ & 579 & 768 & 666 & 96 & 655 & 939 & 766 & 151 \\
\hline Hardness $\left(m g . L^{-1}\right)$ & 57 & 100 & 74 & 23 & 42 & 62 & 52 & 10 \\
\hline Iron $\left(\mathrm{mg} \cdot \mathrm{L}^{-1}\right)$ & 0.32 & 0.37 & 0.35 & 0.03 & 0.34 & 0.45 & 0.41 & 0.06 \\
\hline Copper $\left(\mathrm{mg} \cdot \mathrm{L}^{-1}\right)$ & 0.00 & 0.51 & 0.27 & 0.26 & 0.26 & 0.30 & 0.29 & 0.02 \\
\hline Manganese (mg. $\left.\mathrm{L}^{-1}\right)$ & 0.09 & 1.10 & 0.73 & 0.56 & 1.10 & 1.50 & 1.23 & 0.23 \\
\hline Aluminum (mg. $\left.\mathrm{L}^{-1}\right)$ & 0.05 & 0.13 & 0.09 & 0.04 & 0.03 & 0.11 & 0.06 & 0.05 \\
\hline $\mathrm{TN}$ :TP ratio & 1.44 & 5.58 & 3.95 & 2.19 & 6.84 & 10.98 & 8.68 & 2.11 \\
\hline Trophic State index - TSI & 80.6 & 82.1 & 81.0 & 1.1 & 79.1 & 79.7 & 79.3 & 0.4 \\
\hline
\end{tabular}

\section{TABLE II}

Average values of biomass of cyanobacteria $\left(\mathrm{mm}^{3} \cdot \mathrm{L}^{-1}\right)$ in the Apipucos reservoir during rainy and dry periods; $+=$ occurrence of biomass less than $0.1 \mathrm{~mm}^{3} . \mathrm{L}^{-1}$; $\mathrm{DS}=$ dry season; $\mathrm{RC}=$ rainy season.

\begin{tabular}{l|c|c}
\hline \multicolumn{1}{c|}{ Taxon } & \multicolumn{1}{c}{ DS } & \multicolumn{1}{c}{ RS } \\
\hline Oscillatoriales & & \\
Geitlerinema amphibium (C. Agardh) Anagnostidis & 0.9 & 0.6 \\
$\begin{array}{l}\text { Planktothrix agardhii (Gomont) Anagnostidis and } \\
\text { Komárek }\end{array}$ & 24.9 & 5.3 \\
\hline Chroococcales & & \\
Merismopedia tenuissima Lemmermann & 0.1 & + \\
Microcystis aeruginosa (Kützing) Kützing & 0.4 & 0.2 \\
\hline Nostocales & & \\
$\begin{array}{l}\text { Cylindrospermopsis raciborskii (Woloszynska) } \\
\text { Seenaya and Suba Raju }\end{array}$ & - & 0.2 \\
\hline
\end{tabular}

during the dry period. Geitlerinema amphibium (C. Agardh) Anagnostidis occurred on 100\% of samples, with values ranging from $<0.1 \mathrm{~mm}^{3} . \mathrm{L}^{-1}$ (rainy) and $1.14 \mathrm{~mm}^{3} . \mathrm{L}^{-1}$ (dry). During the rainy season, only the species Planktothrix agardhii (Gomont) Anagnostidis and Komárek $\left(5.3 \pm 4.3 \mathrm{~mm}^{3} . \mathrm{L}^{-1}\right)$ showed average biomass values above $1.0 \mathrm{~mm}^{3} . \mathrm{L}^{-1}$.

The biomass of cyanobacteria was predominantly composed of Planktothrix agardhii (Gomont) Anagnostidis and Komárek in the dry period (mean: $24.9 \pm 4.3 \mathrm{~mm}^{3} . \mathrm{L}^{-1}$ ) and rainy (mean: $5.3 \pm$ $\left.4.3 \mathrm{~mm}^{3} \cdot \mathrm{L}^{-1}\right)$, representing $98.9 \%$ and $96.9 \%$ of the total biomass, respectively.

There was significant difference in biomass of cyanobacteria between periods (ANOVA: $\mathrm{F}=27.75$, $\mathrm{p}<0.05$ ), with values 3.8 times larger in the driest months being observed, however, for the values of chlorophyll-a and phaeophytin the difference was not significant.

The Zeu presented strong negative correlation with the color (Pearson: $p=-0.92$ ), turbidity (Pearson: $\mathrm{p}=-0.90$ ) and biomass of cyanobacteria (Pearson: $\mathrm{p}=-0.93$ ). 


\section{DISCUSSION}

The results of the analyzed parameters were compared with the standards proposed in Brazilian law (BRASIL 2005), for class 2 freshwaters. Seasonal differences in biotic and abiotic factors in the reservoir of Apipucos between 2011 and 2012 provide opportunity to analyze conditions that alter the quality of the water and may cause risks to public health.

Distribution and proliferation of cyanobacteria are commonly influenced by several factors, such as concentration and ratio of nitrogen and phosphorus, light, temperature, oxygen, $\mathrm{pH}$, herbivory and stability of water column, which may act synergistically and antagonistically (Paerl 2008, Fernandes et al. 2009).

Almeida et al. (2012), studying the Apipucos reservoir in the years of 2008 and 2009 noted significant differences between dry and rainy seasons for turbidity, dissolved oxygen and conductivity. This denotes that the profiles of limnological variables of a reservoir are extremely dynamic and portray the reality of that ecosystem at that time. In this study, conducted four years later, the profile was different, with significant differences only being in the $\mathrm{pH}$. With respect to the identification of cyanobacteria, the earlier study indicated Merismopedia sp. as predominant, as opposed to the present where $P$. agardhii took over that position. This once again shows the dynamics of ecology of phytoplankton in eutrophic reservoirs.

In the present work, there was a predominance of $P$. agardhii in both seasons, even with low Zeu extensions, which ranged between $0.62 \mathrm{~m}$ (dry) 1.38 $\mathrm{m}$ (rainy), corroborating with the study by Gemelgo et al. (2009) in reservoirs of São Paulo (Brazil).

The extent of Zeu in ecosystems suffers influence of various factors, such as TDS, turbidity, seasonality, concentration of cells etc. High values of TDS, surpassing even the maximum value allowed in accordance with resolution 357/2005 of Brazilian law (500 mg. $\mathrm{L}^{-1}$, Brasil 2005), must be responsible for the low extent of Zeu presented in this paper, confirming the results of Malmaeus and Hakanson (2003). Although the difference is not significant, the largest TDS values were found in the rainy season, a result supported by Tundisi et al. (2008), and Lira et al. (2011), though not confirmed by Hernández-Atilano et al. (2008).

Works point to seasonality influencing the extent of Zeu in Brazilian ecosystems, highlighting higher values in the rainy seasons (Henry et al. 2006, Chellapa et al. 2008a, b, 2009), corroborating the present work. However, studies done by DellamanoOliveira et al. (2011), Tundisi et al. (2008), Oliveira et al. (2011) and Lira et al. (2011) found a lesser extent of Zeu during the rainy season, due to the input of particles the boarder toward the water.

Throughout the year, the reservoir of the Apipucos Dam presents floating macrophyte $E$. crassipes. According to Tucci and Sant'Anna (2003), this species promotes increased turbidity and decreased nitrogen concentration, being typical of eutrophic environments, including competing with the local phytoplankton for nutrients.

Inverse relationships between transparency of water and biomass of phytoplankton have been reported (Moura et al. 2007b, Chellapa et al. 2009, Costa et al. 2009, Cunha and Calijuri 2011). Some works indicate a dominance of $P$. agardhii in periods with less luminosity and higher turbidity (Chellapa et al. 2009, Kokocinski et al. 2010, Dantas et al. 2011, 2012). Although low absolute values, the turbidity was higher in the dry season compared to the rainy and greater values for this parameter can be more advantageous to cyanobacteria group of Oscillatoriales (Figueredo and Giani 2009) and Nostocales (Tucci and Sant'Anna 2003). Genres such as Microcystis, Planktothrix, Anabaena, (=Dolichospermum) and Nodularia are planktonic, species that are vertical migratory and floating due to the presence of gas vacuoles that aid in flotation. Therefore, they can often dominate and even form blooms in freshwaters ecosystems with lower Zeu extension when the water column stabilizes 
(Fernandes et al. 2009). The reduction of the volume and scant depth of reservoirs in the drought period seem to promote high turbidity, decreasing light availability and favoring the prevalence and increase in biomass of cyanobacteria species adapted for these environmental conditions (Costa et al. 2009). However, it is necessary to ascertain whether the lack of light favors the growth of cyanobacteria or is the result of high cells concentration.

Positive correlation between $\mathrm{pH}$ and phytoplankton has also been found in studies of Dantas et al. (2008) and Cunha and Calijuri (2011). The seasonal variation of $\mathrm{pH}$ can be explained by the increased consumption of $\mathrm{CO}_{2}$ during the summer (Palma et al. 2010). Just as occurred in the study, Fernandes et al. (2009) show that alkaline $\mathrm{pH}$ favors the growth of cyanobacteria. According to this author, the preference of cyanobacteria to neutral and alkaline environments is due to their ability to use bicarbonate as a form of inorganic carbon assimilation and its limited ability to regulate and maintain the internal $\mathrm{pH}$ neutral in acids ecosystems. Moura et al. (2007a) and Lira et al. (2011), studying reservoirs of the Northeast, found alkaline $\mathrm{pH}$ values throughout the year, unlike Moura et al. (2007b), who found most alkaline values only during the dry season, coinciding with greater biomass values.

The decrease in the biomass of cyanobacteria during the rainy season in tropical regions can be explained by the fall in the water column stability in this period, due to the turbulence of the water (Dantas et al. 2008). This factor is sometimes considered more important than the temperature and solar radiation on seasonal adjustment of phytoplankton dynamics in aquatic systems (Figueredo and Giani 2009). In studies conducted in eutrophic reservoirs in Brazil (Henry et al. 2006, Moura et al. 2007b, Dantas et al. 2008, Gentil et al. 2008, Tundisi et al. 2008, Andrade et al. 2009, Costa et al. 2009, Chalar 2009, Cunha and Calijuri 2011, Oliveira et al. 2011, Moura et al. 2011), it was found that the highest densities phytoplanktonic coincided with periods of lower rainfall and higher temperatures, mainly of filamentous species (Costa et al. 2009). However, Oliveira et al. (2011), Lira et al. (2011) and Dantas et al. (2012) found contrary results, possibly due to the drag of nutrients of allochthonous origin, which enriched the ecosystem.

Despite the fact that the biomass of cyanobacteria have been significantly different between periods, the values of chlorophyll-a and phaeophytin did not follow this pattern. This may be due to the fact that this study only considered the community of cyanobacteria, however, other groups of algae were present in the samples and also possess these pigments, confirming the result of Lira et al. (2011).

Throughout the period of study, the reservoir presented limitation by nitrogen. A similar result was obtained by Dantas et al. $(2008,2011)$, who reported this profile in reservoirs of Northeastern of Brazil in function of high concentrations of available phosphorus. However, the TN:TP ratio study is very complex and questioned in the literature as to its use as an exclusive tool to justify blooms of cyanobacteria. In the present work, there was no significant difference between the values of the TN:TP between seasons, although there were significant differences between the values of biomass in the two periods. A study by Figueredo and Giani (2009) indicated the high densities of phytoplankton even with TN:TP ratio $>38$ (limited by phosphorus).

According to Paerl (2008) and Chellapa et al. (2009), low TN:TP ratios favor the growth of cyanobacteria, especially of nitrogen-fixing species (Fernandes et al.2009), confirming the profile observed in the present study, in which the average value of the TN:TP ratio in the dry and rainy seasons were 3.95 \pm 2.19 and $8.68 \pm 2.11$, respectively. Chellapa et al. (2009) found dominance of $P$. agardhii in conditions of low TN:TP. However, Chellapa et al. (2008b), studying a reservoir in the northeast of Brazil, found incompatibility between cyanobacteria and low TN:TP ratio. Finally, Aguirre et al. (2006) and Santos et al. (2012), found no relationship between 
cyanobacterial dominance and TN:TP ratio to the eutrophic reservoir analyzed. For the present study, it seemed clear that the high biomass of cyanobacteria were due to the high concentration of TP. Phosphorus is often cited as limiting the growth of cyanobacteria and, at the same time, as the main cause of blooms, when in excess (Paerl 2008).

For the macronutrients nitrogen and phosphorus, higher concentrations were detected in the rainy and dry season, respectively. For nitrogen, the results are supported by the studies of Moura et al. (2007b, 2011), Dantas et al. (2008), Tundisi et al. (2008), studying reservoirs of the Brazilian Northeast and Rajaniemi-Wacklin et al. (2008), studying eutrophic reservoir in Finland. This can be explained by the allochthonous input of the nutrient carried by the rains. However, studies conducted by Henry et al. (2006), Moura et al. (2007a), Hernández-Altilano et al. (2008), Dellamano-Oliveira et al. (2008) and Silva et al. (2011) detected smaller concentrations of both nutrients during the rainy season, possibly as a result of the dilutive effect of rainfall.

With respect to metals, the works of Paerl (2008) and Willame et al. (2008) make association with copper and iron, respectively; however, the scientific literature still lacks studies in this area. According to those authors, low concentrations of copper favor the growth of cyanobacteria. Although copper concentrations in the reservoir are 200 to 392 times higher than the maximum value allowed by CONAMA Resolution 357, it does not appear to have inhibited the growth of cyanobacteria. Willame et al. (2008) reported negative correlation between growth of Planktothrix and concentrations of iron, corroborating the results of the present study.

Elevated values of conductivity (above 100 $\mu$ s. $\mathrm{cm}^{-1}$, Margalef 1983) show eutrophication of the ecosystem (Tundisi et al. 2008, Gemelgo et al. 2009, Silva et al. 2011), due to the high degree of decomposition of organic matter, which releases greater amount of ions in the water column (Matsukazi et al. 2004), commonly observed in reservoirs of northeast of Brazil (Chellapa et al. 2008b, Costa et al. 2009). In the present work, there were greater conductivity values in the rainy season, a result supported by Oliveira et al. (2011) and Lira et al. (2011). The Apipucos reservoir is used for leisure and recreation of the surrounding population, contributing to the process of eutrophication of the ecosystem, reflected in high conductivity values, corroborating the work of Silva et al. (2011), studying reservoir in Alagoas (northeast of Brazil), used for the same purposes. R-strategists organisms, such as $P$. agardhii, have advantage in eutrophic environments, helping to explain the dominance of this species in this environment. Northeastern reservoirs are abundant in cyanobacteria r-and s-strategists (Costa et al. 2009).

The predominance of cyanobacteria in tropical eutrophic reservoir is due to a number of factors, such as high temperatures, low rainfall, alkaline $\mathrm{pH}$ and high concentrations of nutrients, primarily N and P (Chorus and Bartram 1999, Paerl 2008). The reservoir of Apipucos is target of anthropogenic actions that cause eutrophication of the environment, through the supply of $\mathrm{N}$ and $\mathrm{P}$ arising from issuance of sewage and fishing, among other activities. However, it appears that seasonality has exercised influence on the growth of cyanobacteria and water quality, in spite of the TSI for the present reservoir always show hypereutrophic values. Moura et al. (2007b), Gentil et al. (2008) and Lira et al. (2011), studying Brazilian reservoirs, observed that they remained eutrophic or hypereutrophic during the year, mainly in the drier months.

Allied to this evidence, the presence of bacteria of the coliform group found in this work, including high concentrations of thermotolerant representatives, indicates contamination by domestic sewage and its amount depends on the faecal load that is thrown and the residence time of the water. Studies of Gentil et al. (2008) have detected the presence of these bacteria in eutrophic reservoir.

The dominance of cyanobacteria without striking seasonal variation for long periods is characterized 
as the last stage in the process of eutrophication and is already quite documented in Brazilians eutrophic reservoirs (Costa et al. 2006, Gemelgo et al. 2008, Gentil et al. 2008, Fonseca and Bicudo 2008, Crossetti and Bicudo 2008).

It must be taken into consideration that the species $P$. agardhii is recognized as a potential producer of cyanotoxins (Chorus and Bartram 1999), which can compromise the health of the population that uses this water, as well as the local fish fauna. Works have reported the presence of anatoxin-a (Viaggiu et al. 2004) and microcystins (Vieira et al. 2005, Nguyen et al. 2007, Panosso et al. 2007, Costa et al. 2009) concomitant with blooms of $P$. agardhii. The presence of hepatotoxins implies serious damage to human health and animals that consume contaminated water. Blooms of cyanobacteria are responsible for sporadic, but recurrent, episodes of poisoning and death of domestic animals and human populations, associated with recreational and supply waters (Carmichael 2001). In addition, the accumulation of hepatotoxins in muscles of fish may also occur (Magalhães et al. 2001, Costa et al. 2009), constituting important route of human contamination.

The monitoring water quality with the use of physico-chemical and biological parameters is a practice required by Brazilian law (Resolution 357/2005 ofCONAMA) and, according to the results found here, all parameters are in disagreement with such legislation for class 2 freshwaters, making it unfit for primary contact.

Water quality in Apipucos Dam is strongly influenced by biotic and abiotic factors, suffering action of seasonality. Information on the physicochemical and bacteriological changes obtained in this research provide efficient indicators of anthropogenic changes on ecosystem and demonstrated the possibility of worsening in the health of people who came in contact with this water.

This study represents a significant contribution to determination of water quality in aquatic eco- systems, especially the urban and shallow ones, used for purposes others than the public water supply, taking into account the effect of seasonality.

\section{RESUMO}

Este estudo investigou a qualidade da água em um reservatório eutrófico urbano no Nordeste do Brasil, considerando a influência da sazonalidade. Mensalmente, amostras foram coletadas na sub-superfície do reservatório. As seguintes variáveis abióticas foram analisadas: temperatura, $\mathrm{pH}$, oxigênio dissolvido, cor aparente, turbidez, condutividade, flúor, nitrogênio total, cloretos, sólidos totais dissolvidos, dureza total, ferro, cobre, manganês, alumínio, clorofila-a e feofitina. Coliformes totais e termotolerantes foram analisados de acordo com APHA (2012). A densidade de cianobactérias foi quantificada através de sua biomassa. Os dados foram analisados por meio de análise de variância (one-way ANOVA) e teste de correlação de Pearson. Elevados valores médios de biomassa de fitoplâncton $\left(26.3 \mathrm{~mm}^{3} \cdot \mathrm{L}^{-1}\right)$ ocorreram na estação seca, com destaque para Planktothrix agardhii e Geiterinema amphibium, que ocorreram em 100\% das amostras. Elevado índice de estado trófico foi detectado ao longo do ano. Sazonalidade exerceu alguma influência em variáveis tanto bióticas como abióticas, ocasionando alterações na qualidade da água do reservatório.

Palavras-chave: coliformes, cianobactérias, reservatório, estado trófico.

\section{REFERENCES}

AFFE HJ AND BARBONI SAV. 2012. Cianobactérias potencialmente tóxicas de importância em Saúde Pública. RevInter Revista Intertox de Toxicologia, Risco Ambiental e Sociedade 5(3): 42-59.

Aguirre N, Werding B And PALACIO J. 2006. The nitrogen/ phosphorus and the succession of phytoplankton in two lakes located in the alluvial prairie of main river in Germany. Rev Fac de Ing Univ Antioquia (38): 136-145.

Ahmed W, Yusuf R, Hasan I, Ashraf W, Goonetilleke A, TOZE S AND GARDNER T. 2013. Fecal indicators and bacterial pathogens in bottled water from Dhaka, Bangladesh. Braz J Microbiol 44(1).

Almeida VLS, Melão MGG AND Moura NA. 2012. Plankton diversity and limnological characterization in two shallow tropical urban reservoirs of Pernambuco State, Brazil. An Acad Bras Cienc 84: 537-550. 
ANDRADE CM, GOMES CTS, ARAGÃo NKCV, SILVA EM AND LIRA AST. 2009. Estrutura da comunidade fitoplanctônica com ênfase em Cyanobacteria no reservatório de TapacuráPE. Rev Inst Adolfo Lutz 68(1):109-117.

APHA. 2012. Standard methods for examination of water and wastewater. $22^{\text {nd }}$ ed., USA: American Public Health Association, American Water Works Association and Water Environmental Federation.

BRASIL. 2005. Regulation CONAMA No 357, "Guidelines for classification of water bodies", Official Law Report's, 27, March 2005.

CAlijuri MC, Alves MA AND SAntos ACA. 2006. Cianobactérias e cianotoxinas em águas continentais. São Carlos: Rima Editora, 118 p.

CARLSON RE. 1977. A trophic state index for lakes. Limnol Oceanogr 22(2): 361-369.

CARMiCHAEL WW. 2001. Health effects of toxin-producing cyanobacteria: The CyanoHABs. Hum Ecol Risk Assess 75: 1393-1407.

Chalar G. 2009. The use of phytoplankton patterns of diversity for algal bloom management. Limnologica 39: 200-208.

Chellapa NT, Borba JM AND Rocha O. 2008b. Phytoplankton community and physical-chemical characteristics of water in the public reservoir of Cruzeta, RN, Brazil. Braz J Biol 68(3): 477-494.

Chellapa NT, CÂmara FRA And Rocha O. 2009. Phytoplankton community: indicator of water quality in the Armando Ribeiro Gonçalves Reservoir and Pataxó Channel, Rio Grande do Norte, Brazil. Braz J Biol 69(2): 241-251.

Chellapa NT, Chellapa SL AND Chellapa S. 2008a. Harmful Phytoplankton Blooms and Fish Mortality in a eutrophicated reservoir of Northeast Brazil. Braz Arch Biotechnol 51(4): 833-841.

CHORUS IAND BARTRAM J. 1999. Toxic Cyanobacteria in water: a guide to their public health consequences, monitoring and management. London and New York: WHO.

CoLE GA. 1994. Textbook of limnology. $4^{\text {th }}$ ed., Long Grove: Waveland Press, $412 \mathrm{p}$.

Costa IAS, Azevedo SMFO, SEnNa PAC, Bernardo RR, Costa SM AND CHELLAPA NT. 2006. Ocurrence of toxinproducing Cyanobacteria blooms in a brazilian semiarid reservoir. Braz J Biol 66(1B): 211-219.

Costa IAS, CUnHA SRSC, PANOSSO R, ARAújo MFF, MElo JLS AND ESKINAZI-SANT'ANNA EM. 2009. Dinâmica de cianobactérias em reservatórios eutróficos do semi-árido do Rio Grande do Norte. Oecol Bras 13(2): 382-401.

Crossetti LO AND BiCUdo CEM. 2008. Phytoplankton as a monitoring tool in a tropical urban shallow reservoir (Garças Pond): the assemblage index application. Hydrobiologia 610: 161-173.

CunHa DGF AND CALIJURI MC. 2011. Variação sazonal dos grupos funcionais fitoplanctônicos em braços de um reservatório tropical de usos múltiplos no estado de São Paulo (Brasil). Acta Bot Bras 25(4): 822-831.
Dantas EW, Moura AN AND BitTencourt-Oliveira MC. 2011. Cyanobacterial blooms in stratified and destratified eutrophic reservoirs in semi-arid region of Brazil. An Acad Bras Cienc 83: 1327-1338.

DAntas EW, BitTencourt-Oliveira MC AND Moura AN. 2012. Dynamics of phytoplankton associations in three reservoirs in northeastern Brazil assessed using Reynolds' theory. Limnologica 42: 72-80.

DANTAs EW, MOURA AN, BitTEnCOURT-Oliveira MC, ARRUDA-NETO JDT AND CAVALCANTI ADC. 2008. Temporal variation of the phytoplankton community at short sampling intervals in the Mundaú reservoir, Northeastern Brazil. Acta Bot Bras 22(4): 970-982

Dellamano-Oliveira MJ, Vieira AH, Rocha O, Colombo V AND SANT'ANNA CL. 2008. Phytoplankton taxonomic composition and temporal changes in a tropical reservoir. Fundamental and Applied Limnology / Archiv für Hydrobiologie 171(1): 27-38.

DOWNING JA AND MCCAULEY E. 1992. The nitrogen: phosphorus relationship in lakes. Limnol Oceanogr 37: 936-945.

Esteves FA. 2013. Fundamentos de Limnologia. São Paulo: Interciência, $828 \mathrm{p}$.

Fernandes VO, Cavati B, Oliveira LB and SOUZA BD. 2009. Ecologia de cianobactérias: fatores promotores e consequências das florações. Oecol Bras 13(2): 247-258.

Figueredo CC AND GiANI A. 2009. Phytoplankton community in the tropical lake of Lagoa Santa (Brazil): Conditions favoring a persistent bloom of Cylindrospermopsis raciborskii. Limnologica 39: 264-272.

FonseCA BM AND Bicudo CEM. 2008. Phytoplankton seasonal variation in a shallow stratified eutrophic reservoir (Garças Pond, Brazil). Hydrobiologia 600: 267-282

Gemelgo MCP, MuCCI LJN AND NAVAS-PEREIRA D. 2009. Population dynamics: seasonal variation of phytoplankton functional groups in Brazilian reservoirs (Billings and Guarapiranga, São Paulo). Braz J Biol 69(4): 1001-1013.

Gemelgo MCP, SANT'AnNA CL, TUCCI AT AND BAROBosa H. 2008. Population dynamics of Cylindrospermopsis raciborskii (Woloszynska) Seenayya \& Subba Raju, a Cyanobacteria toxic species, in water supply reservoirs in São Paulo, Brazil. Hoehnea 35(2): 297-307.

Gentil RC, TuCCI A AND SANT'ANNA CL. 2008. Dinâmica da comunidade fitoplanctônica e aspectos sanitários de um lago urbano eutrófico em São Paulo, SP. Hoehnea 35(2): 265-280.

Henry R, NOGUEIRA MG, POMPEO ML AND MOSCHINI-CARLOS V. 2006. Annual and Short-Term Variability in Primary Productivity by Phytoplankton and Correlated Abiotic Factorsin the Jurumirim Reservoir (São Paulo, Brazil). Braz J Biol 66(1B): 239-261.

Hernández-Atilano E, Aguirre NJ, Palacio JA AND RAMÍREZ-RESTREPO JJ. 2008. Variación espacio-temporal de la asociación Fitoplanctónica en diferentes momentos del pulso Hidrológico en la ciénaga de Ayapel (Córdoba), Colombia. Actual Biol 30(88): 67-81.

Hillebrand H, DÜRSElen C, Kirschtel D, Pollingher U AND ZOHARY T. 1999. Biovolume calculation for pelagic and benthic microalgae. J Phycol 35: 403-424. 
KOKOCINSKI M, STEFANIAK K, MANKIEWICZ-BOCZEK J, IZYDORCZYK K AND SOININEN J. 2010. The ecology of the invasive cyanobacterium Cylindrospermopsis raciborskii (Nostocales, Cyanophyta) in two hypereutrophic lakes dominated by Planktothrix agardhii (Oscillatoriales, Cyanophyta). Eur J Phycol 45(4): 365-374.

KOMÁREK J AND ANAGNOSTIDIS K. 1989. Modern approach to the classification system of Cyanophytes, 4: Nostocales. Algol Stud 56: 247-345.

KOMÁREK J AND ANAGNOSTIDIS K. 1999. Cyanoprokayota 1. In: EтTI H et al. (Eds), Chroococcales. Stutgart: Subwasserflora von Mitteleuropa. Gustav Fischer, 548 p.

KOMÁREK J AND ANAGNOSTIDIS K. 2005. Cyanoprokayota 2. In: Bridel B et al. (Eds), Oscillatoriales. Müncher: Subwasserflora von Mitteleuropa. Elsevier GmbH, 759 p.

KomÁREK J AND CRONBERG G. 2001. Some Chroococcalean and Oscilatorialen Cyanoprokaryotes from southern African lakes, ponds and pools. Nova Hedwigia 73: 129-160.

Kosten S, HusZar VLM, MAZZEO N, SCHEFFER M, STERNBERG LSL AND JEPPESEN E. 2009. Ecol Appl 19: 1791-1804.

LIRA GAST, ARAÚJO E, BITTENCOURT-OLIVEIRA MC AND MOURA AN. 2011. Phytoplankton abundance, dominance and coexistence in an eutrophic reservoir in the state of Pernambuco, Northeast Brazil. An Acad Bras Cienc 83: 1313-1326.

Magalhães VF, SOARES RM AND AZEVEdo SMFO. 2001. Microcystin contamination in fish from the Jacarepaguá Lagoon (Rio de Janeiro, Brazil): ecological implication and human health risk. Toxicon 39: 1077-1085.

Malmaeus JM AND HaKANSON L. 2003. A dynamic model to predict suspended particulate matter in lakes. Ecol Model 167: 247-262.

MARGALEF R. 1983. Limnologia. Barcelona, Omega.

MATSUKAZI M, MuCC JLN AND RochA AA. 2004. Comunidade fitoplanctônica de um pesqueiro na cidade de São Paulo. Rev Saúde Pública 38(5): 679-686.

Moura AN, BitTencourt-Oliveira MC, DANTAS EW AND ARRUDA-NETO JDT. 2007B. Phytoplanktonic associations: a tool to understanding dominance events in a tropical Brazilian reservoir. Acta Bot Bras 21(3): 641-648.

Moura AN, DANTAS EW AND BITTENCOURT-Oliveira MC. 2007A. Structure of the Phytoplankton in a Water Supply System in the State of Pernambuco - Brazil. Braz Arch Biol Techn 50(4) 645-654.

Moura AN, Dantas EW, OliveIra HSB AND BITTENCOURTOLIVEIRA MC. 2011. Vertical and temporal dynamics of cyanobacteria in the Carpina potable water reservoir in northeastern Brazil. Braz J Biol 71(2).

Neumann-Leitão S, Nogueira-Paranhos JD and SouZA FBVA. 1989. Zooplâncton do açude de Apipucos, Recife PE (Brasil). Arq Biol Tecnol 32(4): 803-821.

Nguyen LTT, Cronberg G, AnNADOtTer H AND LARSEN J. 2007. Planktic cyanobacteria from freshwater localities in ThuaThien-Hue province, Vietnam. Nova Hedwigia 85(1-2): 35-49.
OliveIra MT, Rocha O AND PERET AC. 2011. Structure of the phytoplankton community in the Cachoeira Dourada reservoir (GO/MG), Brazil. Braz J Biol 71(3): 587-600.

PAERL HW. 2008. Nutrient and Other Environmental Controls of Harmful Cyanobacterial. Adv Exp Med Biol 619: 217-213.

Palma P, Alvarenga P, Palma VL, Fernandes RM, SOARES AMVM AND BARBOSA IR. 2010. Assessment of anthropogenic sources of water pollution using multivariate statistical techniques: a case study of the Alqueva's reservoir, Portugal. Environ Monit Assess 165(1-4): 539-552.

PANOSSO RF, COSTA IAS, SOUZA NR, ATTAYDE JL, CUNHA SRS AND GOMES FCF. 2007. Cianobactérias e Cianotoxinas em reservatórios do Estado do Rio Grande do Norte e o potencial controle das florações pela tilápia do nilo (Oreochromis niloticus). Oecol Bras 11: 433-449.

RAJANIEMI-WACKLIN P, RANTALA A, KUUPPO P, HAUKKA K AND SIVONEN K. 2008. Cyanobacterial community composition in shallow, eutrophic Lake Tuusulanjärvi studied by microscopy, strain isolation, DGGE and cloning. Algol Stud 126: 137-157.

RECIFE. 2000. Lei $n^{\circ}$ 16.609. Diário Oficial do Município de Recife de 18 de dezembro de 2000.

SANTOS MCR, Muelle H AND PACHECO DMD. 2012. Cyanobacteria and microcystins in lake Furnas (S. Miguel Island-Azores). Limnetica 31(1): 107-118.

SiLVA KPB, COSTA MMS AND GUEDES EAC. 2011. Variação temporal do fitoplâncton de um lago pertencente à Área de Proteção Permanente no estado de Alagoas, nordeste do Brasil. Acta Bot Bras 25(4): 890-898.

SiQueIRA DB AND OliveIRA-FILHO EC. 2005. Cianobactérias de água doce e saúde pública: uma revisão. Universitas Ciências da Saúde 3(1): 109-127.

TUCCI A AND SANT'ANNA CL. 2003. Cylindrospermopsis raciborskii (Woloszynska) Seenayya \& Subba Raju (Cyanobacteria): variação semanal e relações com fatores ambientais em um reservatório eutrófico, São Paulo, SP, Brasil. Rev Bras Bot 26(1): 97-112.

Tundisi JG, MATSUMURA-TUNDISI T AND ABE DS. 2008. The ecological dynamics of Barra Bonita (Tietê River, SP, Brazil) reservoir: implications for its biodiversity. Braz $\mathrm{J}$ Biol 68(4): 1079-1098.

Viaggiu E, Melchiorre S, Volpi F, Di Corcia A, Mancini R, Garibaldi L, CRichigno G AND BRUNo M. 2004. Anatoxin-a toxin in the cyanobacterium Planktothrix rubescens from a fishing pond in northern Italy. Environ Toxicol 19: 191-197.

VIEIRA JMS, AZEVEDO MTP, AZEVEDO SMFO, HONDAB RY AND CORRÊA B. 2005. Toxic cyanobacteria and microcystin concentrations in a public water supply reservoir in the Brazilian Amazonia region. Toxicon 45: 901-909.

Willame R, Thys I, JacQuet V, Verbanck M, CAUChIE H AND HOFFMANN L. 2008. Environmental variables involved in the development of bloom-forming cyanobacteria in a meso-to-eutrophic reservoir. Algol Stud 126: 229-249. 